\title{
Kernos
}

Revue internationale et pluridisciplinaire de religion grecque antique

15 | 2002

Varia

\section{Mountain Goddesses in Ancient Thrace: The Broader Context}

\author{
Nikola Theodossiev
}

\section{OpenEdition \\ Journals}

Electronic version

URL: http://journals.openedition.org/kernos/1393

DOI: 10.4000/kernos. 1393

ISSN: 2034-7871

\section{Publisher}

Centre international d'étude de la religion grecque antique

\section{Printed version}

Date of publication: 1 January 2002

ISSN: 0776-3824

\section{Electronic reference}

Nikola Theodossiev, « Mountain Goddesses in Ancient Thrace: The Broader Context », Kernos [Online], 15 | 2002, Online since 21 April 2011, connection on 01 May 2019. URL : http:// journals.openedition.org/kernos/1393; DOI : 10.4000/kernos.1393 


\section{Mountain Goddesses in Ancient Thrace: The Broader Context}

The ancient writers often connect the cult of Phrygian Cybele with mountains and rocky highlands. The goddess was even called Mí $\eta \rho \rho$ 'Opeí $\alpha$ or 'Mountain Mother', as attested in both literary sources and epigraphic evidence. However, other records give us information that similar religious ideas were not confined to Asia Minor and two female deities in ancient Thrace were also associated with mountains, similarly to Cybele. And although there is no written source testifying that these Thracian goddesses were called 'Mount Mother', some evidence might support the conclusion for their appearance as a mountain.

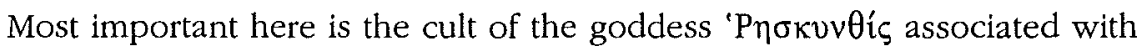
Greek Hera, who was celebrated on the sacred mountain 'P to the mouth of Hebros in Southeastern Thrace, as attested by Nicandrus and his scholiast ${ }^{1}$. This mountain goddess was worshipped together with her

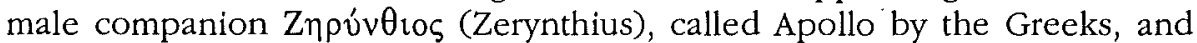
this took place in a temple located on Mount Rheskynthion ${ }^{2}$. The cult of Rheskynthis and Zerynthios was obviously related to the worshipping of

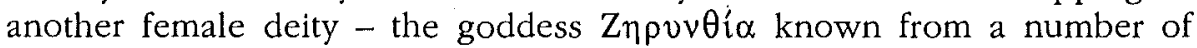
ancient literary records and identified with Hecate, Aphrodite or Rhea ${ }^{3}$. She was a chthonic deity who was honored with dog sacrifices that were

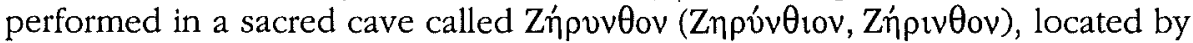
the ancient authors in two different places - on Samothrace or in the opposite mainland near the mouth of Hebros ${ }^{4}$. Similar conflation between the names of the female deities, the sacred mountain and the cave reminds us of the information of Hesychius who explained Kv́ $\beta \varepsilon \lambda \alpha$ like "a mountain in Phrygia, and caves and graves" 5

1 Nicandr., Ther. I, 459-462 Gow-Scholfield; Schol. in Nicandr., Ther., I, 459-462 GowScholfield.

2 Ibid.; T. Liv., XXXVIII, 41, 4 Müller.

3 The main sources on Zerynthia are collected in: D. Detschew, Die thrakiscben Spracbreste, Wien, $1976^{2}$, p. 184-185; $c f$. also Lycophr., Alex., 72-80 Scheer; Nicandr., Ther., I, 462-463 Gow-Scholfield; Schol. in ARISTOPH., Pax, 277-278 Koster; NonN., Dion. XIII, 400 Keydell.

4 Ibid.

5 Hesych., s.v. Kybela Alberti. 
The second deity in Thrace who was associated with a mountain is the goddess $\Gamma \alpha \vee \eta \alpha$ known from a votive inscription on a small altar dated to the Roman Imperial period ${ }^{6}$. It was dedicated to the goddess by Apollonios son of Seuthes, obviously a man of Thracian origin considering his father's name ${ }^{7}$. It is most significant that the altar was found exactly in the region of $\Gamma_{\alpha}^{\prime} v 0 \varsigma^{8}-$ the famous sacred mountain in Southeastern Thrace, called 'I $\varepsilon$ òv ópos by the Greek writers and first attested by Xenophon in the beginning of the 4th century B.C. ${ }^{9}$ In this case the goddess and the sacred mount have identical names again, which supports the conclusion for a mountain aspect of the female deity. At the same time, the important nature of the site is attested by Demosthenes ${ }^{10}$ and Aeschines ${ }^{11}$ who described a residence and treasury of the Odrysian kings Kotys and Kersebleptes located in Hieron Oros. And even more: in a later period Strabo ${ }^{12}$ wrote that the local people worshiped the sacred mountain. This information probably reflects the cult of Ganea.

Actually, a couple of literary records give clear information about other mountains in ancient Thrace that were known as sacred highlands where different cult activities took place. Amongst the most famous ones is Kogaionon, a sacred mount in Northeastern Thrace where the male deity Zalmoxis was worshiped ${ }^{13}$. Another important mountain was Pangaion located in Southwestern Thrace, strongly related to the cult of Orpheus and the Edonian mythical king Rhesos ${ }^{14}$. Of special interest also is Saon (Saos, Samos, Saoke), the high mountain of Samothrace where the mysteries of the Great Gods were celebrated besides other deities that were worshiped on the island $^{15}$. The list of mountains related to different cults in ancient Thrace

6 A. Dumont, Mélanges d'arcbéologie et d'épigraphie, Paris, 1892, p. 420, n. 88 a.

7 On the Thracian personal name Seuthes, of. Detschew, o.c. (n. 3), p. 434-437.

8 ' Ibid., p. 99 with the sources on the mount Ganos and the surrounding region called Ganiada; on Ganiada and a settlement called Ganos $c f$. XENoph., Anab., VII, 5, 8 Masqueray and Aeschin., Kata Ktesipb. III, 82, 6 Blass.

9 Xenoph., Anab. VII, 1, 14 Masqueray; $c f$. also N. Theodossiev, "The Sacred Mountain of the Ancient Thracians", in Studia in bonorem Alexandri Fol, Serdicae, 1995 (Tbracia 11), p. 371-384.

10 Demostr., Contr. Aristocr, 104 Blass; Pbilip., III, 15 Croiset.

11 Aeschin., II. Peri tes parapresb., 90 Martin-Budé.

12 Strabo, VII, fr. 56 Meineke.

13 Detschew, o.c. (n. 3), p. 273 on Kogaionon mount and p. 173-175 on the cult of Zalmoxis.

14 Ibid., p. 349-350 on Pangaion mountain and p. 395-397 on Rhesos; cf. also [Eur.], Rbes., 963-973 Ebener on the cult of Rhesos in Pangaion and AEschyL, Bass., fr. 83 Mette on Orpheus celebrating Helios-Apollo in Pangaion.

15 N. LEwis, Samotbrace. The Ancient Literary Sources, New York, 1958 (Samotbrace I), p. 4, n. 7, p. 7 , n. $16-18$, p. $18-19$, n. 39 , p. 20 , n. 42 , p. $21-22$, n. $45-46$ and p. $38-39$, n. 83 on the mount Saon and passim with ancient literary records on the cults of Samothrace; on the mysteries of the Great Gods see: S.G. Cole, Theoi Megaloi. The Cult of the Great Gods at Samothrace, Leiden, 1984, passim. 
could be prolonged, but there is not any clear information that they were directly associated with female deities. So, one can only speculate that these mountains might represent aniconic images of mountain goddesses similarly to Rheskynthion and Ganos. In the context of all these written sources, very significant is the great number of Thracian sanctuaries located in mountains and rocky highlands that clearly show the sacred nature of the places ${ }^{16}$. Also, it is possible to suppose that the numerous tumuli of ancient Thrace might symbolize sacred mountains and if so, these burial constructions could be related to some cults of mountain goddesses besides their funerary functions ${ }^{17}$.

Similar religious ideas in ancient Thrace should be studied in a broader context. Of course, the closest parallels might be found in the cult of the Phrygian Great Goddess Cybele, usually identified with a Mountain bearing the same name ${ }^{18}$. In a number of epigraphic records from Asia Minor dated to the 4 th -3 rd centuries B.C. and to the Roman Imperial period the goddess was called Mń $\tau \rho \rho$ 'Opeí $\alpha^{19}$. Diodorus also testified that Cybele was known as 'Mountain Mother' ${ }^{20}$ and he described a mountain called Kv́ $\beta \varepsilon \lambda$ s while the goddess was named after this mount ${ }^{21}$. Kv $\beta \varepsilon \dot{\lambda} \lambda$ or Mountains are reported in Orphei Argonautica ${ }^{22}$, besides that Herodianus described Kú $\beta \varepsilon \lambda \alpha$ like a

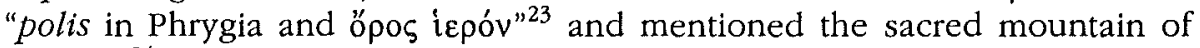
K৩ $\beta \hat{\varepsilon}^{\prime} \mathrm{ol}^{24}$, too. Later on, Herodianus' information was repeated by Stephanus Byzantius $^{25}$ and Hesychius explained Cybele like "a mountain in Phrygia, and caves and graves"26, as cited above. All these sources clearly show the mountain aspect of the goddess.

16 M. DomaradzKI, "Sanctuaires thraces du $\mathrm{II}^{\mathrm{e}}-\mathrm{I}^{\mathrm{er}}$ millénaire av. n.è.", Acta Archaeologica Carpatbica 25 (1986), p. 89-100; id., "Les lieux de culte thraces (deuxième moitié du $\mathrm{II}^{\mathrm{E}}-\mathrm{I}^{\mathrm{er}}$ mill. av. J.-C.)", Helis 3, 1 (1994), p. 69-108.

17 For such a possibility, $c f$. Theodossiev, "The Sacred Mountain" (n. 9); id., NortbWestern Thrace from the Fifth to First Centuries BC, Oxford, 2000 (BAR Inter. Ser. 859), p. 53-55.

18 C. Brixhe, "Le nom de Cybèle", Die Spracbe 25 (1979), p. 40-45; L. Zgusta, "Weiteres zum Namen der Kybele", Die Spracbe 28 (1982), p. 171-172.

19 M.J. Vermaseren, Conpus Cultus Cybelae Attidisque. I. Asia Minor, Leiden, 1987, p. 79, n. 242 from Calchedon; p. 186-187, n. 616-617 and p. 188-189, n. 625, 627 from Ephesus; p. 214-215, n. 723 from Apollonia Salbake; p. 217, n. 729 from Oinoanda; p. 218, n. 731 from Nisa; p. 226-227, n. 751, 754 from Ariassus; p. 230, n. 764 from Bağlü.

20

21

22

23 Herodian., De prosod. cathol., I, 381 Lentz.

24 Ibid., I, 322 Lentz.

25 SтерH. Byz, s.v. Kybeleia Meineke.

26 Hesych., s.v. Kybela Alberti. 
Following these ideas, some epithets of the Great Goddess in Asia Minor are also important. Strabo wrote that on a hill close to Lampsakos there was a sanctuary of Meter Theon called Tń $\rho \varepsilon\left\llcorner\alpha^{27}\right.$. At the same time, the mountain of the goddess Tereia was located near Kyzikos, being known to Homer ${ }^{28}$ and described again by Strabo ${ }^{29}$. Later on, Hesychius wrote that Tereia was a mountain in Troas ${ }^{30}$. Very clear evidence comes from some epigraphic records, too. Thus in numerous inscriptions Meter Theon was called $\Sigma ı \pi v \lambda \eta v \eta^{31}$, obviously a name that originated from Sipylos mountain, and in a similar way the Great Goddess was called with another mountain epiclesis: $\Delta \mathrm{v} \delta \delta \mu \eta \dot{\eta} v \eta^{32}$ coming from Dindymon (Dindyma). Actually, this way of giving the goddess a name derived from different mountains in Asia Minor is well described by Strabo ${ }^{33}$.

All these testimonia concerning the cults of mountain goddesses probably reflect some relations between ancient Phrygians and Thracians, and even may show that the origins, of the Phrygian people lay in the Northern Balkans, as attested in literary records and recently confirmed in archaeological material from Gordion ${ }^{34}$. On the other hand, the Phrygian

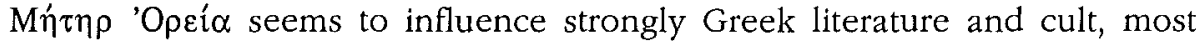
clearly attested in the image of goddess Rhea being called 'Mountain Mother'. A similar syncretic process could be traced back in the literary works of the late 5th century B.C. Thus Aristophanes ${ }^{35}$ and Euripides ${ }^{36}$ described Rhea

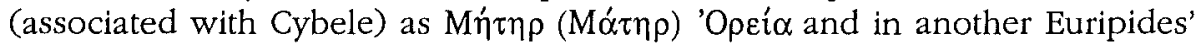

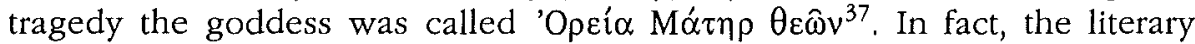
image of Rhea as a 'Mountain Mother' was probably created in the interaction zones of Asia Minor, where the idea had been borrowed from the

27 Strabo, XIII, 1, 17 Meineke; cf. A.B. Соoк, Zeus. A Study in Ancient Religion. II, Cambridge, 1925 , p. 697.

28 Hom., Il. II, 828-830 Ameis-Hentze.

29 Strabo, XII, 4, 6; XIII, 1, 10 et 17 Meineke.

30 Hesych., s.v. Tereia Alberti.

31 Vermaseren, o.c. (n. 19), p. 31, n. 80 from Geveze; p. 161-163, n. 543-546, p. 164-165, n. $549-551$, p. 167, n. 555 , p. 169, n. 564 , p. $171-172$, n. 571 , p. $172-173$, n. $575-576$, p. $174-175$, n. 580 , p. $175-176$, n. $582-584$ from Smyrna.

32 Ibid., p. 81, n. 251 from Apamea Myrlea (?); p. 96, n. 290 from Cyzicus; p. 230-231, n. 765 from Çarik Saray; p.238-239, n. 791 from Laodicea Combusta; $c f$. Herodian., De prosod. catbol., I, 333 et 382 Lentz and STEPh. BYZ., s.v. Dindyma Meineke.

33 Strabo, X, 3, 12 Meineke.

34 L.E. Roller, "The Phrygian Mother Goddess and her Thracian Connections", in Eight International Congress of Tbracology. Thrace and the Aegean (Summaries), Sofia Yambol, 2000, p. 76-77; O.W. Muscarell.A, "The Iron Age Background to the Formation of the Phrygian State", BASOR 299-300 (1995), p. 91-101. 
non-Greek people. A similar proposal might be supported by a scholion to Apollonius Rhodius ${ }^{38}$, referring to a sanctuary of 'Opeí $\alpha$ Mí $\tau \eta \rho$ at Sangarios, which was described by the Greek logographer Xanthos from Lydia who lived in the 6th-5th centuries B.C. The literary image of the 'Mountain Mother' survived into the Roman Imperial period, as attested by Antistius ${ }^{39}$ : 'Oprí $\alpha$

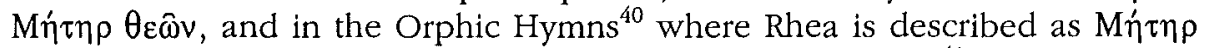
'Opeıouvís. It is interesting that in another Orphic Hymn ${ }^{41}$ Gaia was also

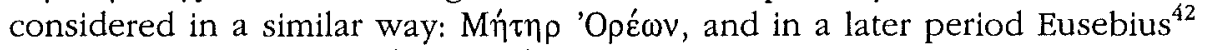
called the goddess П $\alpha \mu \mu \eta \dot{\tau} \tau \omega \rho$ 'Opé $\omega v$.

At the end of this paper, another epigraphic record should be mentioned. On a Late Hellenistic silver bowl from Barbara and Lawrence Fleischman

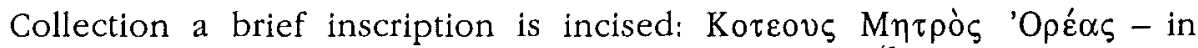
translation "Koteous [son/servant] of Mountain Mother" 43 . And although the provenance of the hoard is unknown, it is possible to suppose that the vessel comes either from Asia Minor or from ancient Thrace. In both cases however, this inscription is remarkable evidence for religious ideas and cults related to the mountain appearance of the goddess. A future comparison between the written sources mentioned here and the archaeological material may help to define more clearly the cult of the mountain goddesses in ancient Thrace and their relationship to other female deities worshiped in Asia Minor and Greece.

Department of Archaeology

Nikola THeOdossiev

Sofia University St. Kliment Ohridski

bul. Tsar Osvoboditel 15

SOFIA 1000

Bulgaria

e-mail: nikolatc@sf.icn.bg

38 Scbol. vet. in APOLl. RHOD., Argon., II, 722 Wendel.

39 ANTisT., Ep., 1-2 Waltz.

40 Orph. Hymn. XXXI. Hymn. curet., 5 Quandt.

41 Orph. Hymn. XV. Dios, 4 Quandt.

42 Euseb., Praep. evang. III, 9, p. 100a-105d Dindorf.

43 A Passion for Antiquities. Ancient Art from the Collection of Barbara and Lawrence Fleiscbman, Malibu, 1994, p. 229-231; cf. a detailed study of the inscriptions in N. Theodossiev, "KOTEOYC H $\triangle I O Y$ and KOTEOYC MHTPOC OPEAC", Hermes 129, 2 (2001), p. 279-283. 